\title{
Estudio de los enlucidos de yeso de la iglesia de San Pedro de los Francos de Calatayud
}

\author{
Study of plaster finishes on San Pedro de los Francos \\ church at Calatayud
}

\author{
R. Bustamante ${ }^{(*)}$ y Ma I. Sánchez de Rojas ${ }^{(*)}$
}

Recepción/Received: 16-II-06

Aceptación/Accepted: 23-X-06

\section{RESUMEN}

El estudio de los enlucidos de la iglesia de San Pedro de los Francos de Calatayud ha permitido demostrar, en primer lugar, la secuencia estratigráfica mediante la lectura de la interfase de adherencia; en segundo lugar, la evolución de las técnicas de aplicación, desde el enlucido mudéjar, un fingido de piedra agramilado y pintado (siglo $X V$ ), hasta los enlucidos lisos y pinturas aplicados posteriormente. $Y$, finalmente, a través de los estudios de microscopía electrónica de barrido (SEM), microanálisis por energía dispersiva de rayos $X(E D X)$ y de difracción de rayos $X(D R X)$, se ha determinado que son morteros en los que tanto el conglomerante como el árido son yeso y anhidrita, que correspondería a un yeso tradicional multifase, cuyos granos más gruesos analizados como áridos proceden del producto obtenido artesanalmente.

Palabras clave: yeso, anhidrita, mortero, proporción de mezcla, mudéjar.

\section{SUMMARY}

This study of the plaster finishes on San Pedro de los Francos Church at Calatayud revealed, firstly, the stratigraphic sequence based on the interpretation of the bonding interfaces; and secondly, the evolution of placement techniques from mudéjar style textured and painted false stonework (15th century) to the smooth plastering and paint typical of later phases. Finally, scanning electron microscope (SEM), energy dispersive $X$-ray microanalysis (EDX) and X-ray diffraction (XRD) studies showed that gypsum and anhydrite are the main components of both binder and aggregate in these mortars. In other words, they constitute traditional multiphase plasters whose coarser particles or aggregate were a byproduct of the artisanal manufacturing process.

Keywords: gypsum, anhydrite, mortar, mix proportions, mudéjar.

\section{INTRODUCCIÓN}

La iglesia de San Pedro de los Francos está situada en el casco histórico de Calatayud y es una obra representativa del gótico aragonés. Fue construida en la segunda mitad del siglo XIV, aunque podría ser más antigua la

\section{INTRODUCTION}

San Pedro de los Francos Church, located in the historic quarter of Calatayud, is representative of Aragonese Gothic architecture. It was built in the 14th century, although the Islamic construction techniques used in the

(*) ETSI Arquitectura, Universidad Politécnica de Madrid, Madrid (España).

(*) Instituto de Ciencias de la Construcción Eduardo Torroja, CSIC, Madrid (España). 
torre desmochada en 1840 , de técnica constructiva islámica (1). El mal estado de conservación de la iglesia motivó la realización de trabajos de emergencia y de estudios previos (2) a las obras de restauración iniciadas en el 2002 y que facilitó la toma de las muestras.

En la construcción de esta iglesia se han usado materiales tradicionales como el barro para levantar los cajones de tapial sobre las cabeceras de muros de ladrillo, piezas aplantilladas para formar los baquetones de los pilares y las nervaduras de las bóvedas, y, en particular, el yeso en distintas formas, teniendo en cuenta su abundancia en esta región geográfica. La base de piedra aljez de uno de los pilares demuestra su uso en la obra, como material amorfo se ha usado en los trabajos de albañilería y para confeccionar las celosías de las ventanas del ábside, y alabastro en la portada de pies, que por su pureza es idóneo para el tallado.

\subsection{La secuencia estratigráfica}

Con el fin de modernizar el interior de la iglesia se realizaron diversas actuaciones y, en algunas partes, se habían sobrepuesto los enlucidos y las pinturas. Por ejemplo, ha sido posible reconstruir in situ la secuencia estratigráfica de los revestimientos del lado de la epístola, muro sur, y de los pilares de la iglesia salón, con una datación sustentada en la información histórica.

El enlucido más antiguo está aplicado sobre una fábrica de ladrillos de $45 \mathrm{~mm}$ de grueso, $1 / 4$ de palmo aragonés aproximadamente (3), levantado con tendeles de $15 \mathrm{~mm}$ de espesor. Este grueso es similar al de la torre, pues según Sanmiguel Mateo, el ladrillo de la torre es de $14 \mathrm{x}$ $28 \times 4,5 \mathrm{~cm}$ y el de la iglesia es de $15 \times 30 \times 3,5 \mathrm{~cm}$, por lo que ambas fábricas, que están situadas en el lado sur, podrían corresponder a una misma fase constructiva. El enlucido está hecho con la técnica mudéjar del agramilado, Figura 1. Es un despiece de buena confección y, posteriormente, sobre el mismo se ha aplicado un enlucido liso, con un fingido de sillería pintado en tono beige con juntas blancas, hacia 1700, que, posteriormente, fue pintado en color gris con juntas blancas, imitando otra sillería de similares características (posible siglo XIX).

Por otro lado, los pilares presentan una secuencia de dos enlucidos, Figura 2. El más antiguo es un agramilado, posiblemente del siglo XVI, debajo de un enlucido liso sobre el que han aplicado tres capas de pinturas.

\subsection{La interfase de adherencia}

Las otras secuencias estratigráficas se han obtenido mediante la lectura de la interfase, cara posterior y cara anterior de las muestras y del puente de adherencia. Fue de utilidad en acabados que habían sido tower -whose upper part was demolished in 1840suggests an earlier origin for this element (1). The poor state of repair of the church occasioned certain emergency works and studies (2) prior to initiation of the restoration work in 2002, which facilitated sample taking.

Traditional materials were used in church construction, such as the earthen fill over rows of brick in masonry walls, moulded elements for the reeding on columns and vault ribs and in particular various forms of gypsum, a material found in abundance in the area. The gypsum rock at the base of one of the columns is proof that it was used not only as an amorphous material in mason$r y$, but for actual construction, as well as in the lattice work on the windows in the apse and in the form of pure alabaster, ideal for sculpting, on the main portal.

\subsection{Stratigraphic sequence}

The church underwent a number of different remodels which in some areas involved replastering and repainting over existing plaster or paint finishes. The stratigraphic sequence of the surfacing on the epistle or south side as well as on the columns on this hall church, for instance, was reconstructed in situ and dated with the aid of historic information.

The oldest plaster was placed on a masonry wall made of $45-\mathrm{mm}$ (or approximately $1 / 4$ Aragonese palm) high brick with $15-\mathrm{mm}$ bed joints. This is similar to the height of the bricks in the tower, which according to Sanmiguel Mateo measure $14 \times 28 \times 4.5 \mathrm{~cm}$ compared to the church brick dimensions of $15 \times 30 \times 3.5 \mathrm{~cm}$. Given that the two walls are located on the south side, then, they may have been built during the same stage of construction. Mudéjar style textured plastering was used (Figure 1). This fine false stone plasterwork was covered over in about 1700 with smooth plaster, which was painted beige to imitate cut stone with white joints; subsequently (perhaps in the $19^{\text {th }}$ C.) this surface was painted grey with white joints to mimic another sort of stonework.

The columns, in turn, were found to have two layers of plaster (Figure 2).Older, textured work, possibly dating from the $16^{\text {th }}$ century, was found underneath a smooth plaster with three layers of paint.

\subsection{Bonding interface}

Other stratigraphic sequences were deduced from marks on the interface, the outer and inner sides of the samples and the bond. This was useful in finishes that had been removed or were concealed, providing information 


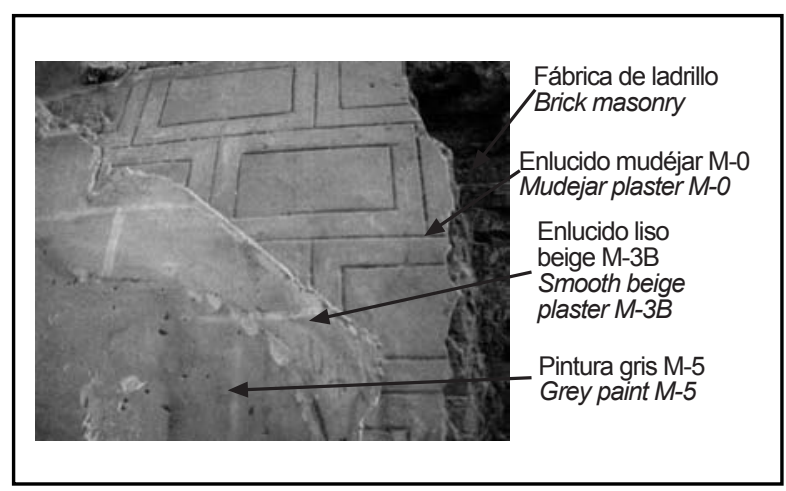

Figura 1. Secuencia estratigráfica de tres revestimientos en el lado de la epístola.

Figure 1. Stratigraphic sequence of three epistle side surfaces.

removidos o que están ocultos, aportando datos sobre despieces de fingidos, dimensiones y colores, pero también sobre el sistema constructivo de la aplicación. Además de la humedad que aporta el mortero fresco y el soporte, la unión fue posible por las juntas rehundidas del agramilado y principalmente por el repicado, Figura 2, para lograr la adherencia de los enlucidos nuevos y antiguos.

\section{ESTUDIOS EXPERIMENTALES Y DISCUSIÓN DE RESULTADOS}

\subsection{Estudio físico-químico}

En una fase previa se identificó el conglomerante mediante el uso de un colorímetro SMART, con filtro con múltiples longitudes de onda, obteniéndose por separado los contenidos de sulfatos y de calcio que se aproximaron a la relación estequiométrica del sulfato cálcico en dos muestras, lo cual sirvió de orientación cualitativa para confirmar la presencia de yeso (4). También se

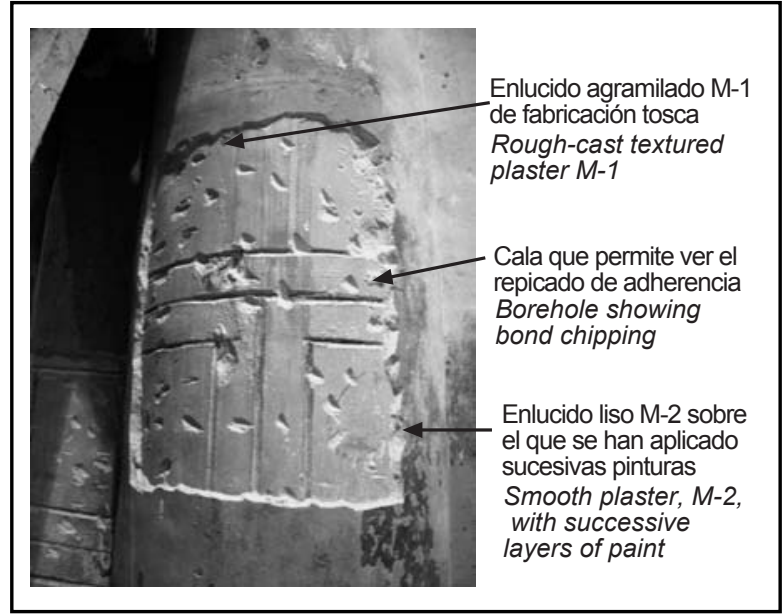

Figura 2. Superposición de dos enlucidos mediante repicado en pilar de la iglesia.

Figure 2. Plaster on a church column chipped to apply a new layer.

not only on false stonework designs, sizes and colours, but also on the construction system used. The old and new plaster bonded thanks to the moisture in the fresh mortar and the underlying surface and the indented joints in the textured plaster, but primarily to surface chipping (Figure 2).

\section{EXPERIMENTAL STUDIES AND DISCUSSION OF RESULTS}

\subsection{Physical-chemical study}

In a preliminary phase, the binder used was identified with a SMART multi-wavelength colorimeter. The sulphate and calcium contents, which were determined separately, were very near the stoichiometric ratio of the calcium sulphate found in two samples, serving as qualitative proof of the presence of gypsum (4). The variations in certain physical properties such as density,

Tabla 1 / Table 1

Resultados físico-químicos

Physical-chemical properties

\begin{tabular}{|c|c|c|c|}
\hline $\begin{array}{l}\text { Datos } \\
\text { Data }\end{array}$ & $\begin{array}{c}\text { M-0 (fines XIV - primera mitad XV) } \\
\left.\text { M-0 (late } 14^{\text {th }} \text { - first half } 15^{\text {th }} C_{\text {. }}\right)\end{array}$ & $\begin{array}{c}\text { M-1 (posible siglo XVI) } \\
\text { M } 1 \text { (possibly 16th } C \text {.) }\end{array}$ & $\begin{array}{c}\text { M-2 (fecha desconocida) } \\
\text { M } 2 \text { (date unknown) }\end{array}$ \\
\hline $\mathrm{pH}$ & 8.00 & 8.20 & 8.20 \\
\hline Densidad aparente $\gamma /$ Bulk density $\gamma$ & $1.58 \mathrm{~g} / \mathrm{cm}^{3}$ & $1.6 \mathrm{~g} / \mathrm{cm}^{3}$ & $1.55 \mathrm{~g} / \mathrm{cm}^{3}$ \\
\hline Coeficiente de absorción $C_{a}$ / Absorption coefficient $C_{a}$ & $11.63 \%$ & $9.73 \%$ & $13 \%$ \\
\hline Porosidad abierta $\beta$ / Open porosity $\beta$ & $18.44 \%$ & $15.53 \%$ & $20.3 \%$ \\
\hline Dureza superficial U Shore C / Shore-C hardness, U & $67 \mathrm{u}$ & $45 \mathrm{u}$ & $73 \mathrm{u}$ \\
\hline Espesor del mortero / Mortar thickness & 15 mm (1 capa / 2 layer) & $8 \mathrm{~mm}$ ( 2 capas / 2 layers) & 5 mm (1 capa / 1 layer $)$ \\
\hline
\end{tabular}


determinaron las variaciones de algunas propiedades físicas (Tabla 1), en cuanto a densidad, coeficiente de absorción, porosidad abierta y dureza superficial Shore C.

Las muestras proceden del tramo central del lado de la epístola, M-0 y M-3B, de uno de los pilares de la nave central (M-1 ligeramente cóncava) y de las bóvedas (M-2 y $M-3 A$ ). La disminución del espesor de los enlucidos tiene su explicación en que el existente se convierte en el enfoscado de la nueva aplicación.

\subsection{Estudio mineralógico}

Posteriormente, se realizaron los estudios mediante SEM, energía dispersiva de rayos $X$ y difracción de rayos $X$, que a continuación se detallan sobre cuatro muestras diferentes en sus características constructivas y de acabado. Por separado se analizaron, la costra o pátina, la fracción fina o cementante (conglomerante) y la fracción gruesa o árido.

Los equipos utilizados son un microscopio electrónico de barrido JEOL, modelo JSM 5400 con análisis semicuantitativo EDX y un difractómetro de rayos X Philips PW-1730.

\subsubsection{Muestra M-0 de origen mudéjar}

Esta muestra es del costado izquierdo del órgano de la iglesia, que fue montado entre 1450 y 1480 . El enlucido es anterior o coetáneo a su colocación, porque el agramilado no está pintado en el borde de contacto con la parte inferior del mueble. La fotografía de la Figura 1 fue tomada después de que el órgano fuera desmontado para ser reparado, dejando el hueco que se aprecia a la derecha. En la Figura 3 se aprecia en la cara posterior de la muestra, el grueso del ladrillo y que los tendeles son de junta rehundida.

El enlucido tiene $15 \mathrm{~mm}$ de espesor y está aplicado en una sola capa. La masa es de color yeso moreno, contiene nódulos de cal, arcilla y fibras. La superficie agramilada y pintada delimita un rectángulo de $40 \mathrm{~cm}$ de ancho por 30 $\mathrm{cm}$ de alto, con un encintado de color beige oscuro de $5 \mathrm{~cm}$ de ancho y un plinto de color salmón de $30 \mathrm{~cm} \times 20 \mathrm{~cm}$. absorption coefficient, open porosity and Shore-C hardness were also found (Table 1).

The samples were taken from the mid-section of the epistle side (M-O and M-3B), one of the columns in the central nave (slightly concave $M-1)$ and the vaults (M-2 and $M-3 A)$. The declining thickness of the successive finishes can be explained by the fact that the existing layer served as the rendering for each new plaster.

\subsection{Mineralogical study}

The SEM, energy dispersive $X$-ray and $X$-ray diffraction results for four samples with different construction and finish characteristics are discussed below. The crust or patina, fine or cementitious fraction (binder) and the coarse or aggregate fraction were analyzed separately.

The equipment used consisted in a JEOL JSM 5400 scanning electron microscope equipped for semi-quantitative EDX analysis and a Philips $P W$ - 1730 X-ray diffractometer.

\subsubsection{Sample M-0, mudéjar origin}

This sample was taken from the wall to the left of the church organ. The finish is prior to or contemporaneous with the 1450-1480 construction of the organ because the textured plaster is not painted along the edge that borders the lower part of the frame. The photo in Figure 1 was taken after the organ was removed for repair, baring the area on the right. The brick height and the indented bed joints can be seen on the inner side of the sample shown in Figure 3.

The plaster consists in a single 15-mm thick layer. The dark gypsum coloured paste contains limestone, clay and fibre nodules. The textured, painted surface describes a pattern of $40-\mathrm{cm}$ wide by $30-\mathrm{cm}$ high rectangles bordered by a dark beige band $5 \mathrm{~cm}$ wide; the false stones in the salmon-colour plinth measure $30 \times 20 \mathrm{~cm}$. The

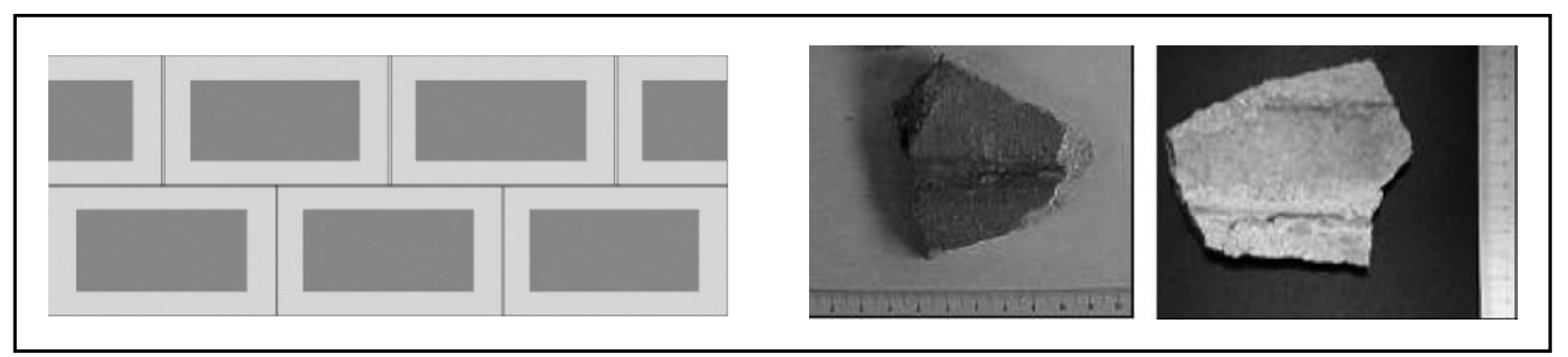

Figura 3. Izda. Dibujo del enlucido M-0. Detalle del agramilado pintado rojo sobre negro. Cara posterior con mortero sobre junta rehundida. Figure 3. Left. Drawing of M-O plaster. Detail of the texturing and red on black paint. Inner side showing ridge where the mortar projected into the joint. 
Las incisiones cóncavas del agramilado tienen $9 \mathrm{~mm}$ de ancho y $3 \mathrm{~mm}$ de profundidad, con dos pigmentos sobrepuestos, rojo sobre negro, este último $3 \mathrm{~mm}$ más ancho a los costados para acentuar visualmente su profundidad. $\mathrm{Si}$ coexistieron ambos pigmentos, o el color rojo fue un repinte hecho con posterioridad, es difícil de identificar al haberse aplicado encima el enlucido $\mathrm{M}-3$.

Las dimensiones y la proporción 4:3 del rectángulo corresponde más bien a la imitación de una sillería que a una fábrica de ladrillo. Difiere en las dimensiones, aunque es similar a la decoración de la iglesia de San Félix de Torralba de Ribota (restaurada bajo la dirección del arquitecto Joaquín Soro desde 1981), cuya ornamentación terminó en 1410 el alarife Mahoma Rami, quien estuvo en Calatayud durante la construcción de San Pedro Mártir (5). En San Félix el trazado de los fingidos es más pequeño, de $30 \times 15$ $\mathrm{cm}$ de alto, con encintados de $2,5 \mathrm{~cm}$ de ancho.

Este mortero tiene como componente principal el yeso, tanto en la fracción gruesa (árido), Figura 4, como en la fracción fina (cementante), Figura 5. En el microanálisis de la fracción fina, también se encontraron formaciones ricas en calcio (Figura 6).

La costra o pátina es también de yeso (Figura 7), observándose además una formación que podría corresponder a un compuesto de naturaleza orgánica (rico en carbono y/o hidrógeno), Figura 8, por la lentitud en la adquisición de los datos y por el pico a baja energía. Al realizarse el estudio de difracción de rayos $\mathrm{X}$ se detectó la presencia concave indents around the false stones are nine $\mathrm{mm}$ high and three $\mathrm{mm}$ deep, with two overlaid pigments: red on black, the latter three millimetres wider on the sides to accentuate the depth. The existence of the subsequent layer of plaster, M-3, makes it difficult to determine whether the two pigments co-existed or the red was a subsequent repaint.

The dimensions and 4:3 proportions of the rectangles indicate that it was stone rather than brick masonry work that the plaster was intended to imitate. Although the dimensions vary, the workmanship is similar to the decoration found in San Félix de Torralba Church at Ribota (restored under the orders of architect Joaquín Soro beginning in 1981), executed in 1410 by master mason Mahoma Rami, who was in Calatayud during the construction of San Pedro Mártir Church (5). The San Félix false stones are smaller, measuring $30 \times 15 \mathrm{~cm}$ and surrounded by $2.5-\mathrm{cm}$ bands.

The main component of the plaster is gypsum, both in the coarse (aggregate) (Figure 4) and fine (cementitious) (Figure 5) fractions. The microanalysis of the fine fraction also revealed calcium-rich formations (Figure 6).

The slow count rate and the low energy peak found for the crust or patina, also made of gypsum (Figure 7), are indicative of a formation that may be an organic compound (rich in carbon and/or hydrogen) (Figure 8). The $X$-ray diffraction assays detected the presence of clay (illite) in the crust (Figure 9). These trials confirmed that

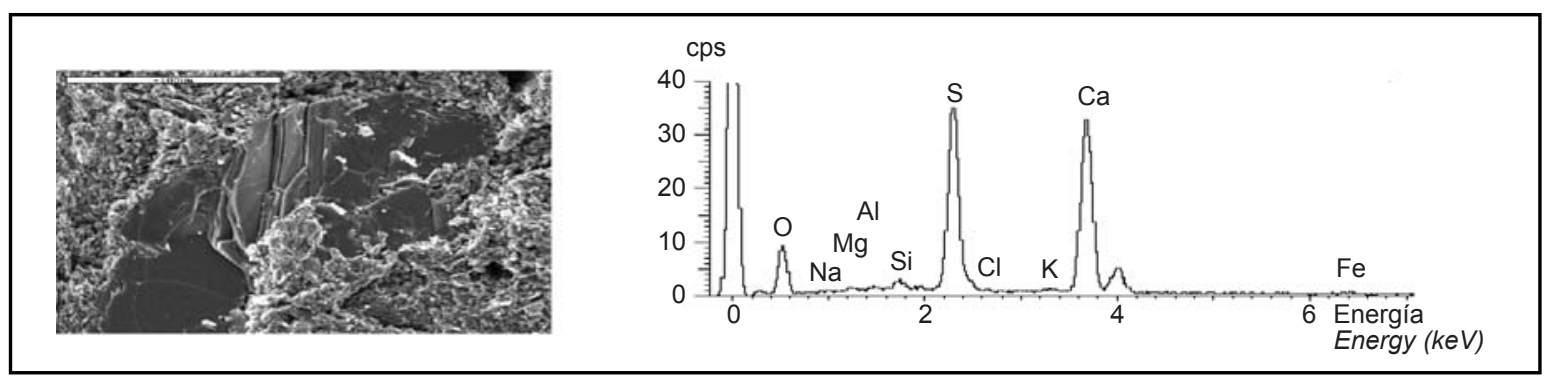

Figura 4. Micrografía SEM y Microanálisis EDX: árido de yeso de muestra mudéjar.

Figure 4. SEM micrograph and EDX microanalysis: gypsum aggregate in the Mudéjar sample.

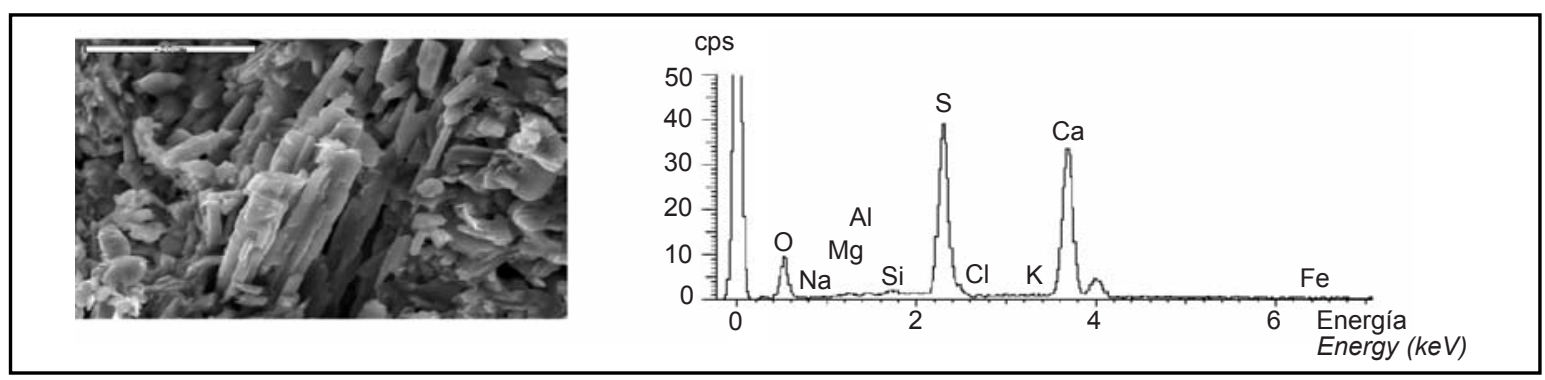

Figura 5. Micrografía SEM y Microanálisis EDX: fracción cementante de M-0.

Figure 5. SEM micrograph and EDX microanalysis: M-O cementitious fraction. 


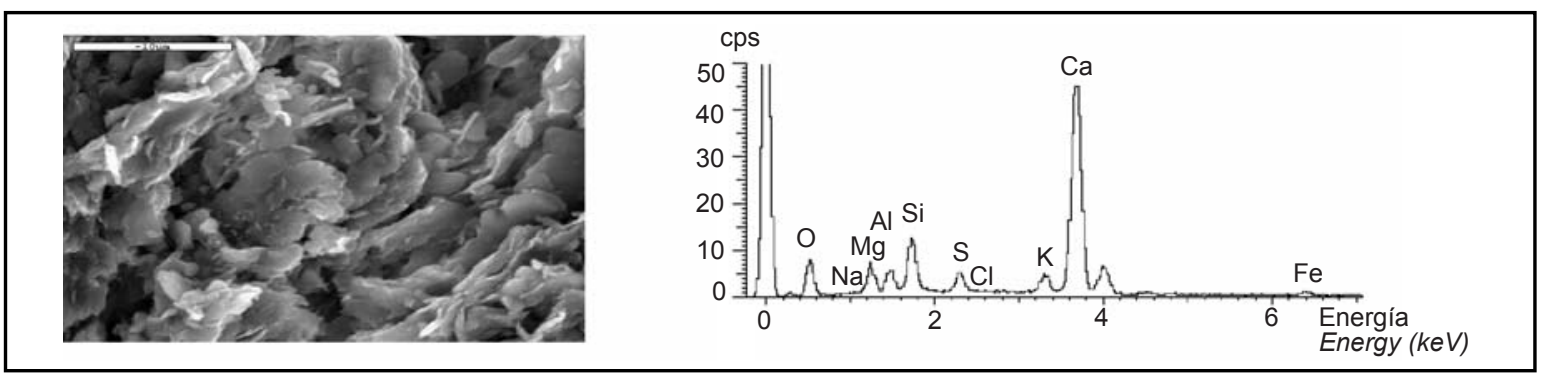

Figura 6. Micrografía SEM y Microanálisis EDX: formaciones ricas en calcio.

Figure 6. SEM micrograph and EDX microanalysis: calcium-rich formations.

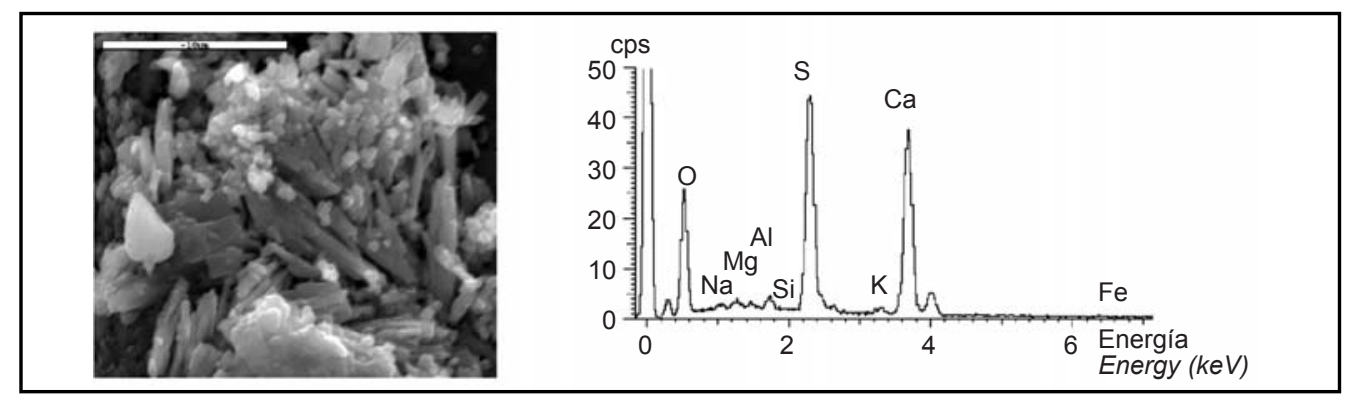

Figura 7. Micrografía SEM y Microanálisis EDX: costra de yeso de la muestra M-0.

Figure 7. SEM micrograph and EDX microanalysis: gypsum crust on sample M-O.

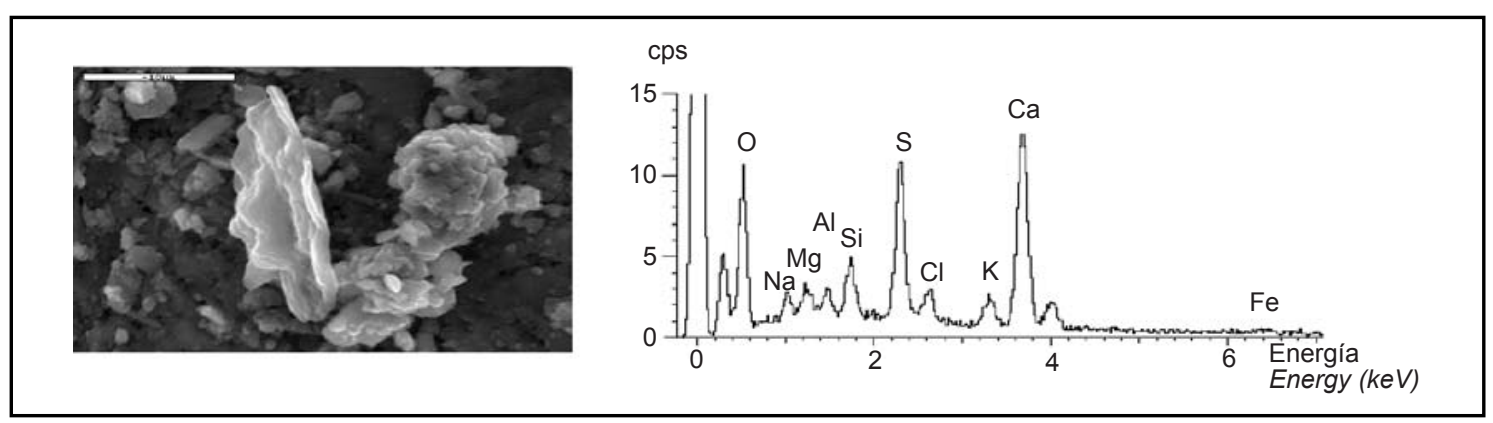

Figura 8. Micrografía SEM y Microanálisis EDX: posible acumulación de producto de naturaleza orgánica en la costra. Figure 8. SEM micrograph and EDX microanalysis: possible accumulation of organic product in the crust.

de arcillas (illita) en la costra (Figura 9). Se confirmó que el principal componente es el yeso en las fracciones fina y gruesa (áridos), con presencia de anhidrita, y algo de cuarzo (Figura 10). La relación en peso de la muestra es: fracción fina/fracción gruesa 0,729, o igual a 1:11/4.

\subsubsection{Muestra $\mathrm{M}-1$}

Corresponde a un enlucido de $8 \mathrm{~mm}$ de espesor, aplicado en dos capas, la primera de $2,5 \mathrm{~mm}$ y la segunda de $5,5 \mathrm{~mm}$. La masa es de color yeso moreno y la superficie tiene una veladura de color marfil. La presencia de cenizas se explica por la calcinación del material en los hornos de leña. La molienda manual mediante cedazos y cribas y el amasado correspondiente eran operaciones previas al trabajo artístico de los alarifes (3). El agramilado pintado en negro de 4 a $5 \mathrm{~mm}$ de ancho por $2 \mathrm{~mm}$ the main component of the fine and coarse (aggregate) fractions is gypsum with some anhydrite and quartz (Figure 10). The ratio of the sample by weight is: fine/coarse fraction $=0.729$, i.e., equal to $1: 11 / 4$.

\subsubsection{Sample $M-1$}

Here the plaster, $8 \mathrm{~mm}$ thick, consists in two layers, the first $2.5 \mathrm{~mm}$ and the second $5.5 \mathrm{~mm}$ thick. The dark gypsum colour of the mix is softened by a marble tone scumble on the surface. The presence of ash is the result of wood furnace calcination. The material was hand ground, strained, sieved and mixed before the master masons set to their artistic work (3). The plaster texturing consisted in cutting bands 4 to $5 \mathrm{~mm}$ high and $2 \mathrm{~mm}$ deep into the mortar with a 


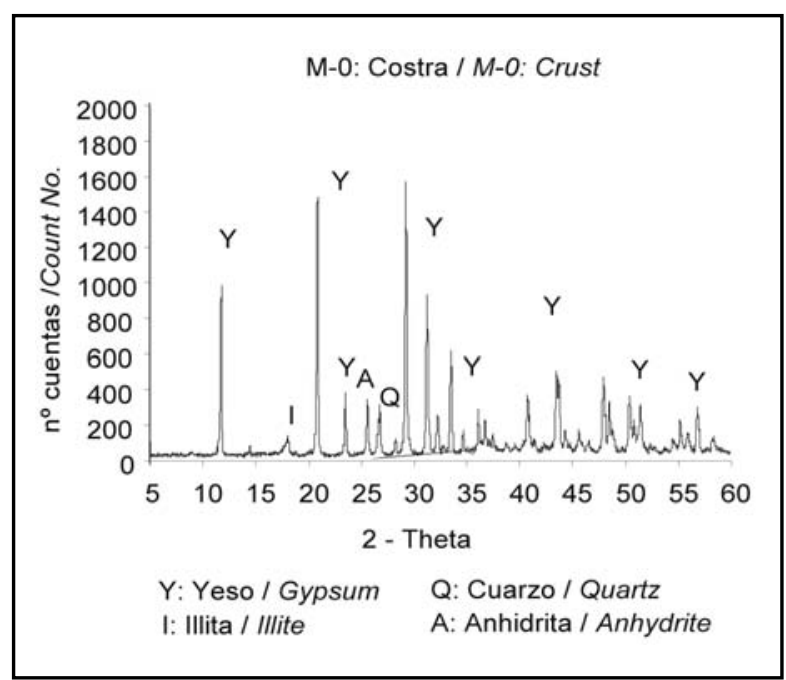

Figura 9. Difracción de Rayos X: costra de la muestra mudéjar $\mathrm{M}-0$.

Figure 9. X-ray diffraction: crust on sample M-0, Mudéjar origin.

de profundidad, hechas con un llaguero fino, define un encintado de $4 \mathrm{~cm}$ de ancho (Figura 11).

Aunque el despiece es similar al del enlucido del fuste del pilar, Figura 2, la sección y la composición del mortero son diferentes. Posiblemente es de una intervención del siglo XVI, porque tiene características similares a los revocos de las iglesias de Fuentes de Jiloca, San Juan de Torrijo de la Cañada y la Colegiata de Daroca.

Esta muestra también tiene como componentes principales el yeso y la anhidrita, tanto en las fracciones finas como en las gruesas, e inclusive en las costras. Sin embargo, la presencia de partículas de forma laminar cuyo análisis indica un alto contenido en $\mathrm{Mg}$ en el conglomerante (Figura 12), la diferencia de la muestra mudéjar. El árido tiene un contenido de sílice (cuarzo) muy bajo. El yeso es también el componente principal de las costras, con presencia de illita y de sílice en muy baja proporción. La relación en peso de la muestra es: fracción fina/fracción gruesa 0,966, o igual a 1:1.

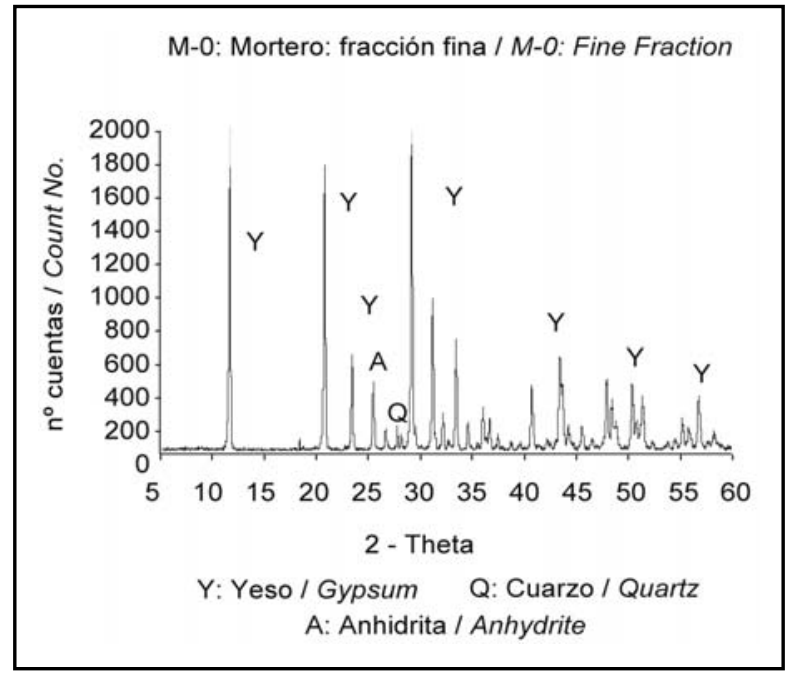

Figura 10. Difracción de Rayos X: fracción cementante de la muestra mudéjar M-0.

Figure 10. $X$-ray diffraction: cementitious fraction on sample M-O, Mudéjar origin.

fine jointer; these bands were subsequently painted black (Figure 11).

Although the false stonework patterns here and on the column shaft are similar (Figure 2), the section and composition of the mortar differ. It may date from the $16^{\text {th }}$ century, for it resembles the rough casting on the church at Fuentes de Jiloca, San Juan Church at Torrijo de la Cañada and Daroca Collegiate Church.

Gypsum and anhydrite are also the main components of the fine and coarse fractions as well as the crust of this sample. The presence of laminated particles whose analysis revealed a high Mg content in the binder (Figure 12), however, sets it apart from the Mudéjar sample. The aggregate has a very low silica (quartz) content. Gypsum is likewise the main component of the crusts, with low proportions of illite and silica. The ratio by weight in the sample is: fine/coarse fraction $=0.966$ or 1:1.
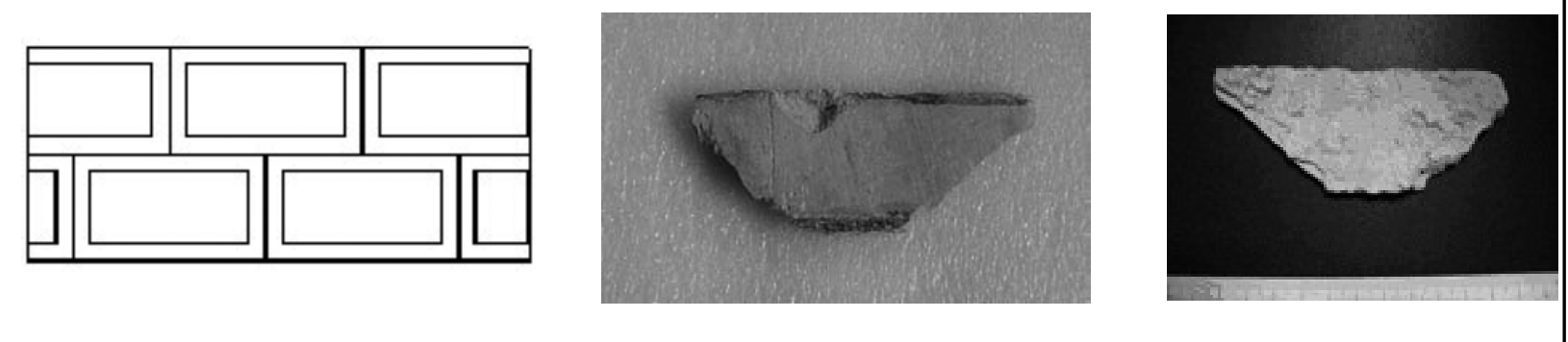

Figura 11. Dibujo del fingido de sillería M-1. Vista del encintado de la cara superficial. Cara posterior.

Figure 11. Drawing of sample M-1 false stonework. Inner side. 

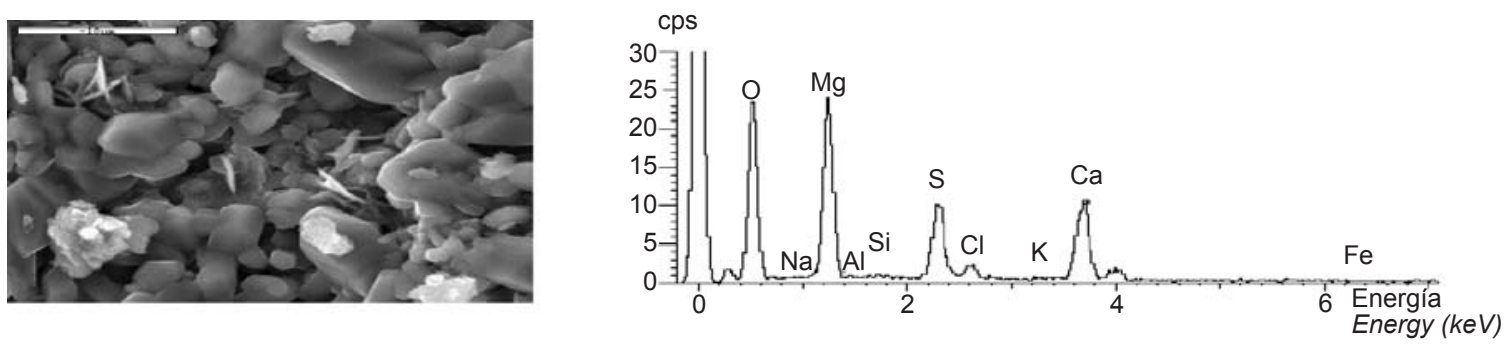

Figura 12. Micrografía SEM y Microanálisis EDX: partículas laminares con alto contenido en magnesio.

Figure 12. SEM micrograph and EDX microanalysis: laminated particles with a high magnesium content.

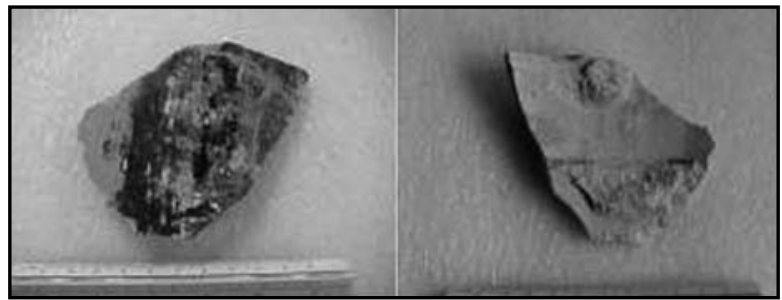

Figura 13. Muestra M-2 con tres pinturas superpuestas en la superficie. Cara posterior con restos de su aplicación sobre enlucido agramilado $\mathrm{M}-1$.

Figure 13. Sample M-2 with three successive layers of paint on the surface. Inner side with traces of the bond to the sample M-1 textured plaster.

\subsubsection{Muestra $\mathrm{M}-2$}

Es de un enlucido liso de $5 \mathrm{~mm}$ de espesor aplicado sobre un mortero $M-1$, que fue repicado como se aprecia en la Figura 2. La cara posterior conserva las pellas de adherencia y los cordones del agramilado pintado negro que definen un encintado de $4 \mathrm{~cm}$ de ancho (Figura 13). La masa es ligeramente menos oscura, también contiene cenizas, y la cara superficial ha sido pintada sucesivamente sobre un acabado ocre amarillo, primero con pintura negra y finalmente en un tono gris, similar este último al fingido de sillería de los muros de color gris con juntas blancas realizado posiblemente en el siglo XIX.

La muestra es de yeso, al igual que las anteriores, con presencia de árido calizo (Figura 14). En la costra también

\subsubsection{Sample $M-2$}

This sample was taken from a 5-mm thick layer of plaster applied over sample M-1 mortar, which was chipped as shown in Figure 2. Bonding pellets and the 4-cm wide protuberances, stained with black paint, that filled the underlying textured pattern can be seen on the inner side (Figure 13). The plaster mix is slightly lighter in tone and also contains ashes; the yellow-ochre painted finish was successively repainted, first black and later grey. The latter finish is similar in tone to the false stonework with white joints possibly painted in the $19^{\text {th }}$ century.

This, like the preceding samples, is made of gypsum with some limestone aggregate (Figure 14). The crust contains,

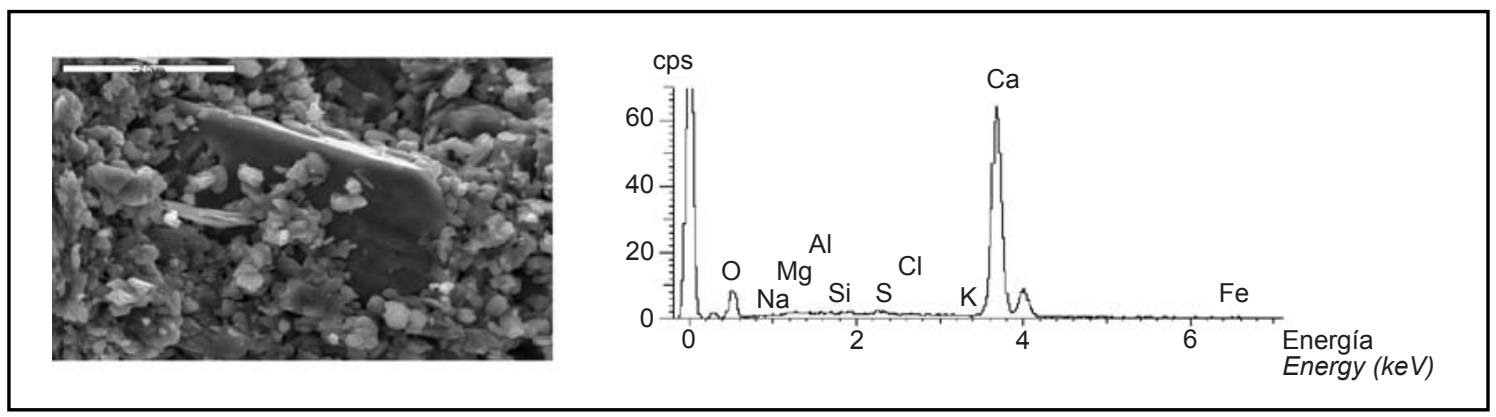

Figura 14. Micrografía SEM y Microanálisis EDX: Árido calizo en la muestra M-2.

Figure 14. SEM micrograph and EDX microanalysis: limestone aggregate in sample M-2. 


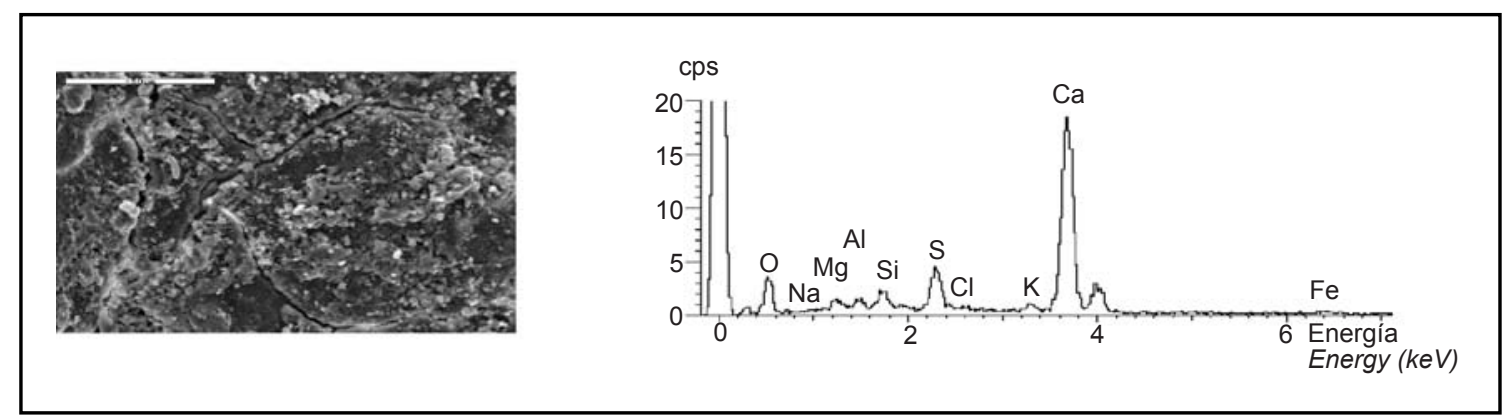

Figura 15. Micrografía SEM y Microanálisis EDX: lechada de cal con material orgánico.

Figure 15. SEM micrograph and EDX microanalysis: lime grout with organic material.

se encuentran arcillas y algún producto orgánico no identificado, que corresponderían a las pinturas sucesivas que tuvo el enlucido (Figura 15). La relación en peso de la muestra es: fracción fina/fracción gruesa $0,680,0$ igual a $1: 1 \frac{1}{2}$.

\subsubsection{Muestras $M-3 A$ y $M-3 B$}

Se cuenta con dos muestras del mismo revestimiento aplicado sobre diferentes soportes. La muestra M-3B, Figura 16, procede del costado izquierdo del órgano y corresponde a un enlucido aplicado sobre el enlucido mudéjar, cuyo agramilado se aprecia en la cara posterior en bulto y pigmentado en rojo.

La cara superficial conservó el color original beige porque una tabla colocada al costado del órgano impidió su cubrición con pintura de color gris. Por consiguiente, es anterior al año 1700, o de la misma fecha en que el órgano gótico fue modernizado por Francisco de Sesma (5).

Forman parte de toda la masa de este mortero, el yeso, la anhidrita y la sílice, con impurezas de titanio en el árido. La costra también tiene yeso, anhidrita, illita y cal, por lo que el acabado fue una lechada de cal evidentemente (Figuras 17 y 18). La relación en peso de la muestra es: fracción fina/fracción gruesa 0,914, o igual a $1: 1$. in addition, clay and an unidentified organic product, the remains of successive layers of paint (Figure 15). The ratio by weight in the sample is: fine/coarse fraction $=0.680$, or $1: 1 \frac{1}{2}$.

\subsubsection{Samples $M-3 A$ and $M-3 B$}

These two samples of the same plaster were placed on different substrates. Sample M- 3B, Figure 16, taken from the wall to the left of the organ, was applied over Mudéjar plaster, whose textured pattern and red pigment left an imprint on the inner side.

The outer side preserves the original beige tone because it was covered by a plank on one side of the organ that prevented it from being repainted grey. Consequently, it must be prior to or concurrent with the date of Francisco de Sesma's modernization of the Gothic organ, i.e., 1700 (5).

This mortar contains gypsum, anhydrite and silica throughout, with titanium impurities in the aggregate. The composition of the crust - gypsum, anhydrite, illite and lime- indicates that the finish was obviously a lime grout (Figures 17 and 18). The ratio by weight in the sample is: fine/coarse fraction $=0.914$, or $1: 1$.

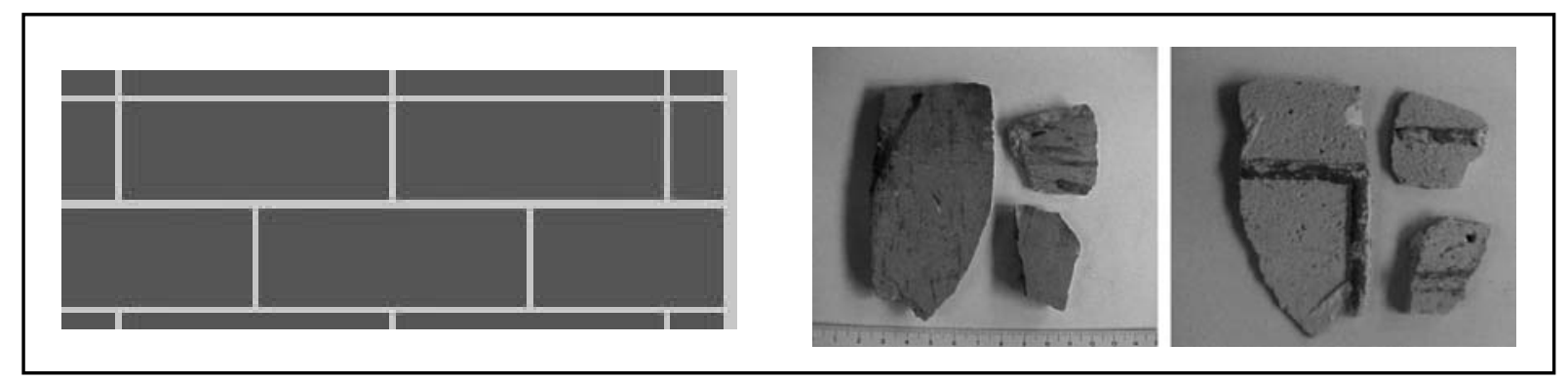

Figura 16. Dibujo del despiece pintado. Superficie del enlucido M-3B. Cara posterior con la impronta del agramilado del enlucido mudéjar M-0. Figure 16. Drawing of the painted stonework pattern. Outer surface of plaster M-3B. Inner side with the imprint made by the M-O Mudéjar textured finish. 


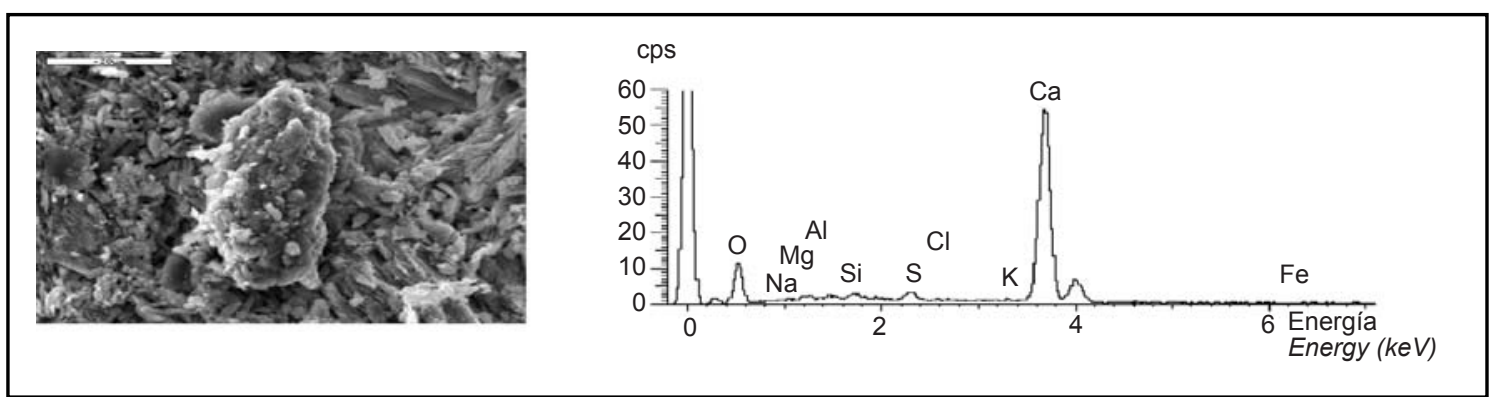

Figura 17. Micrografía SEM y Microanálisis EDX: conglomerante de la muestra M-3B, con depósitos ricos en cal en la costra. Figure 17. SEM micrograph and EDX microanalysis: sample M-3B binder with lime-rich deposits in the crust.

La otra muestra, M-3 A, tiene de 3 a 5 mm de espesor. Procede de las bóvedas de la nave central, y en la superficie exterior presenta un fingido pintado de sillería gris con juntas blancas (M-5). La pintura está aplicada sobre una capa blanca de imprimación previa, sobre el enlucido existente. Los tendeles y llagas blancos de $15 \mathrm{~mm}$ de espesor forman un despiece de sillares de $48 \mathrm{~cm}$ de ancho por $23 \mathrm{~cm}$ de alto. Es el revestimiento que tenía la iglesia antes de ser restaurada (Figura 19).

Esta pintura cubre a su vez a otro despiece fingido pintado en color beige, marrón claro, con juntas blancas de $15 \mathrm{~mm}$ de espesor (M-3B) que se describió en el apartado 2.2.4. La cara posterior conserva el despiece pintado del enlucido existente (Figura 20) y que se describe a continuación.

\subsubsection{Revestimiento $M-4$}

Así se identifica a este revestimiento impreso en la cara posterior de la muestra M-3A. Se trata de la pintura de un fingido de ladrillos rojos colocados a soga con tacos de cerámica de color azul, más tendeles y llagas blancas de $10 \mathrm{~mm}$ de espesor. Habiéndose comprobado durante las
The other sample, M-3A, is 3 to $5 \mathrm{~mm}$ thick. Taken from the vaults over the central nave, its outer surface is painted grey with white joints to imitate false stonework (M-5). The paint was applied over a white primer that coated the existing plaster. The white, $15-\mathrm{mm}$ thick bed joints and perpends form a pattern of false stones $48 \mathrm{~cm}$ wide by $23 \mathrm{~cm}$ high. This was the finish visible in the church before its restoration (Figure 19).

This paint covers the painted beige and light brown false stonework design with 15-mm joints (M-3B) described in item 2.2.4. The inner side of the sample conserves the painted design lifted from the existing plaster (Figure 20) described below.

\subsubsection{Finish $M-4$}

This is the denomination given to the finish imprinted on the inner surface of sample M-3A. It consists in paint imitating red brick arranged in a stretcher bond with blue ceramic billets and 10-mm white bed joints and perpends. The restoration operations uncovered this type of imitation

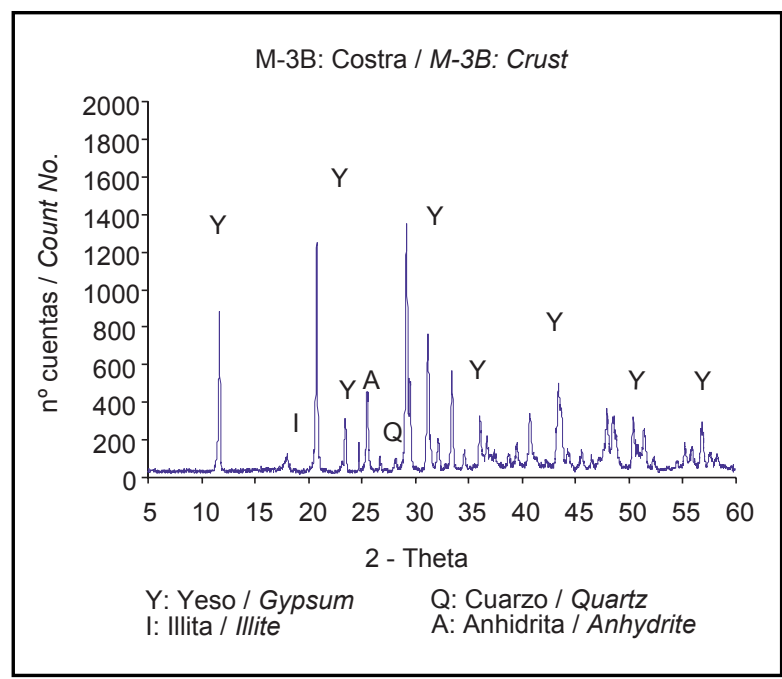

Figura 18. Difracción de Rayos X: costra de la muestra M-3B. Figure 18. $X$-ray diffraction: crust on sample $M-3 B$. 


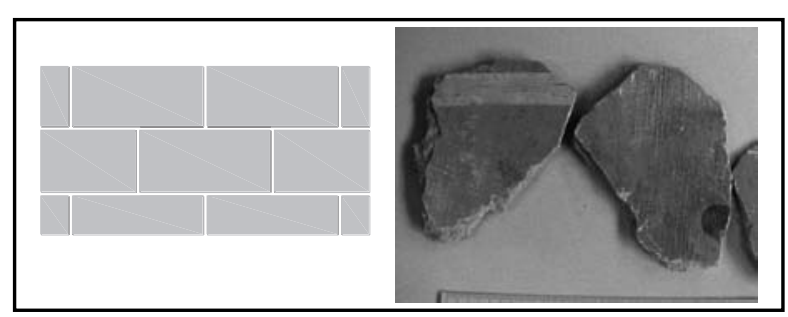

Figura 19. Dibujo de la pintura M-5 aplicada sobre el enlucido M-3B. Cara anterior de la muestra M-3A. Figure 19. Drawing of M-5 paint on M-3B plaster. Inner side of sample $M-3 A$.

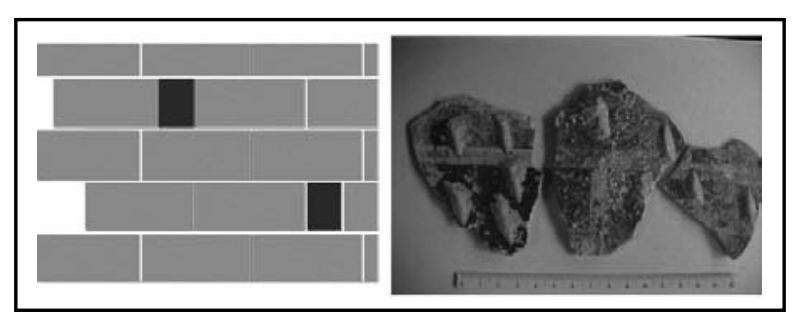

Figura 20. Cara posterior de la muestra M-3 A: interfase de adherencia e impronta del revestimiento M-4. Dibujo del despiece fingido $M-4$.

Figure 20. Inner side of sample M-3A: bonding interface and $M-4$ imprint. Drawing of false stonework design in M-4. Inner side of sample M-3A.

stonework on the vaults. The date it was chipped (plaster pellets adhering to the outer surface) to apply $M-3 B$ is unknown. This was the finish restituted in a critical restoration project undertaken by architect José $M^{a}$ Velero.

\subsection{Discussion}

Fifteenth century Mudéjar decoration combined false salmon-beige textured plaster on walls with painted imitation brick and tile work on vaults. While the other two finishes covered walls and vaults, early $18^{\text {th }}$ century smooth plaster M-3B was first painted beige to imitate stonework and subsequently repainted grey, possibly in the $19^{\text {th }}$ century.

The tests conducted confirmed that the gypsum was obtained by uneven calcination of crude gypsum at temperatures ranging from $80-100{ }^{\circ} \mathrm{C}$, the minimum needed to produce semi-hydrated gypsum $\left(\mathrm{SO}_{4} \mathrm{Ca} 1 / 2 \mathrm{H}_{2} \mathrm{O}\right)$, up to $300{ }^{\circ} \mathrm{C}$, which yields the soluble and insoluble anhydrite $\left(\mathrm{SO}_{4} \mathrm{Ca}\right)$ found in the mortars analyzed. This artisanal procedure determined the nature of the gypsum, with the added advantage that the anhydrite retarded setting, facilitating placement.

Consequently, the coarser particles, analyzed here as aggregate, were actually a product of the grinding process, which is why the fine and coarse fractions are chemically identical. These plasters cannot be readily defined as what are known today as pastes or mortars. Since the composition of the material is the same throughout, they could be regarded to be pastes, but at the same time their particle size differences, which renders the material stronger and more compact, qualifies them as mortars.

Masons, obliged to make use of all the gypsum manu-

factured, including the sieving discards (6), may have
La existencia de granos crudos como resultado de la cocción desigual en hornos de leña, tal vez fue un hecho conocido

tanto los granos más gruesos que se han analigruesa. No es fácil clasificar a estos enlucidos como pastas o morteros, dentro de los conceptos actuales porque, pastas. Aunque se trata de morteros al existir una gra nulometría variada que además le confiere al material más compacidad y por consiguiente resistencia. 
por los albañiles, que aprovecharon las prestaciones de este producto como árido, descubierto casualmente o no, al tener que hacer uso de todo el yeso que fabricaban para una obra, incluidos los desechos que salían del cernido (6).

\section{CONCLUSIONES}

- El estudio estratigráfico de los enlucidos confeccionados con un material de uso local ha permitido reconstruir la evolución decorativa y constructiva de los acabados interiores, apoyándose en los escasos datos históricos de la obra de la iglesia.

- La presencia de yeso y anhidrita en la confección de los morteros desde la época mudéjar obedecería a que se trata de un yeso multifase obtenido en la producción artesanal. Y que las cenizas, arcillas, fibras vegetales, lechadas de cal, etc., son adiciones históricas usadas para influir en las propiedades físicas, mecánicas y acabado superficial de los enlucidos.

- Comparando la relación en peso de las fracciones analizadas, y teniendo en cuenta que el material es el mismo en ambas, la dosificación en volumen de los morteros varía de $1: 1$ a 1:1 1/2 (fracción fina: fracción ruesa). Si se mezclaron separadamente corresponde a la relación conglomerante:árido.

- Tratándose de morteros tradicionales de yeso y teniendo en cuenta su antigüedad, el coeficiente de absorción en masa menor de $15 \%$ puede estimarse como óptimo, y constituye un dato de referencia en el estudio de morteros de estas características.

- La lectura de la interfase de adherencia del enlucido nuevo sobre el enlucido existente, actuando este último como enfoscado, ha proporcionado información sobre el sistema constructivo. La adherencia se ha conseguido mediante el repicado previo, y las costras de acabado de las superficies habrían contribuido a que la separación se ha producido en la interfase y no por rotura de la sección de los enlucidos. been aware of the existence of coarse particles as a result of uneven heating in wood furnaces and taken advantage of the benefits that using aggregate afforded, discovered by chance or otherwise.

\section{CONCLUSIONS}

- The evolution of interior finishes was reconstructed on the grounds of a stratigraphic study of plaster made with a locally abundant material, drawing from the scant historic data available on the construction of this church.

- The presence of gypsum and anhydrite in the mortars made from the Mudéjar age onward was the result of the multi-phase structure of the gypsum obtained with artisanal production methods. The ashes, clay, plant fibres, lime grouting and so on are historic additions used to alter the physical and mechanical properties and surface finish of these plasters.

- Further to the ratio by weight of the fractions analyzed, and inasmuch as they are made of the same material, the dosage by volume in the mortars was found to vary from $1: 1$ to $1: 11 / 2$ (fine fraction:coarse fraction). If the fractions were mixed separately, these numbers would reflect the binder:aggregate ratio.

- Given the age of these traditional gypsum mortars, an absorption coefficient by mass of under $15 \%$ can be regarded to be optimum and constitute a reference figure for the study of mortars of these characteristics.

- A study of the bonding interface between new and existing plasters, in which the latter serves as a previous layer, furnished information on the construction system used. Bonding was achieved by preliminary chipping and the fact that the samples separated along the interface rather than across plaster sections was in part due to the finishes on the respective outer surfaces.

\section{BIBLIOGRAFÍA / BIBLIOGRAPHY}

(1) Sanmiguel Mateo, A.: Torres de ascendencia islámica en las comarcas de Calatayud y Daroca, Ed. Centro de Estudios Bilbilitanos, Zaragoza, 1998, p. 304.

(2) Lauret, B., Monjo, J., Oliveros, J. y Valero, J. M.: "Análisis of the structural behaviour of San Pedro de los Francos of Calatayud", $12^{\text {th }}$ International Brick/Block Masonry Conference, Madrid, 2000.

(3) Borrás, G.: Arte mudéjar aragonés, Tomo I, Ed. Caja de Ahorros y Monte de Piedad de Zaragoza, Aragón y Rioja, y Colegio Oficial de Arquitectos Técnicos y Aparejadores de Zaragoza, 1984.

(4) Bustamante, R., Monjo, J., Valero, J. M. y Villanueva, L. de: "Análisis de la ornamentación interior de la iglesia de San Pedro de los Francos de Calatayud", VII Jornada Nacional Aplicaciones Arquitectónicas de Materiales, ETSAM_UPM, mayo, 2003.

(5) Diputación de Aragón IPHE: El órgano de San Juan El Real de Calatayud, 2001, p. 43.

(6) Cuella Esteban, O.: Aportaciones culturales y artísticas del Papa Luna (1394-1423) a la ciudad de Calatayud, Institución Fernando El Católico de Zaragoza, Centro de Estudios Bilbilitanos de Calatayud, 1984. 